\title{
EFFECT OF EXECUTIVE COMPENSATION, REPRESENTATIVES OF FEMALE CFO, INSTITUTIONAL OWNERSHIP AND COMPANY SIZES ON TAX AGRESSIVITY MEASURES
}

\author{
Shie Fen, Ernie Riswandari \\ University of Bunda Mulia \\ eriswandari@bundamulia.ac.id
}

\begin{abstract}
Tax revenue is the main source of Indonesia's revenue. On the other side, tax payer consider tax as an expense that should be minimized because it can reduce economic ability of companies. This is the reason why companies want to do same aggressive tax planning. The purpose of this research is to analyse the effect to executive compensation, CFOs female representation, institutional ownership, and firm size on tax aggressiveness. This research used 47 sample of manufacturing firms listed in Indonesian Stock Exchange with an observation period of 3 years so that the number of samples used in this study were 141 companies that acquired by purposive sampling method. The method of research analysis was used multiple regression analysis. The result of this research showed that simultaneously, executive compensation, CFOs female representation, institutional ownership, and firm size has significant effect on tax aggressiveness. Partially, executive compensation has significant effect on tax aggressiveness. While the CFOs female representation, institutional ownership, and firm size has no significant effect on tax aggressiveness. The results of this research conclude that executive compensation is one of effective to minimize tax expense. On the other way, it indicates the larger amount of executive compensation will increase the level of tax aggressiveness.
\end{abstract}

Keywords: Executive compensation, CFOs female representation, institutional ownership, firm size, tax aggressiveness.

\section{INTRODUCTION}

Tax as the largest source of state revenue from the non-oil and gas sector is the main source of national development that is continuously carried out by the state which aims to improve people's welfare. The source of funding from the tax sector is a manifestation of the country's independence in terms of development. The tax obtained by the state is managed and used for the benefit of the entire country and its people. But on the other hand, the company considers the tax imposed on the income they receive as an expense.

The assumption that tax is a burden that will affect the profits available to be shared or reinvested makes the company feel it is important to carry out tax payment efficiency. The status of companies that go public or not will affect the dividend distribution policy. Companies that have gone public generally tend to be more high profile than companies that have not gone public. In order for its stock market prices to increase, company managers 
who go public will try to look their best, succeed, and share large dividends. Likewise, the payment of taxes will be tried as well as possible. But whatever the assumption, economically tax is a profit deduction element that is available to be shared or reinvested by the company. In business practices, generally employers identify tax payments as a burden so that the company will try to maximize efficiency and competitiveness so managers must reduce costs as optimally as possible. Likewise with the obligation to pay taxes because the cost of taxes will affect the decline in profit after tax (after tax profit), the rate of return (rate of return), and cash flow (cash flows). The company conducts tax planning with the aim of minimizing tax payments that must be made by the company. To minimize the tax burden borne by the taxpayer, it can be reached by means of engineering which is still within the scope of taxation beyond the taxation provisions permitted by Law No. 36 of 2008.

According to Rori (2013) tax planning is an effort to minimize taxes often referred to as tax planning techniques. Tax planning is a legal effort that can be utilized by the company. This action is legal because tax savings are only done by utilizing things that are not regulated in the provisions of taxation (loopholes).

According to Gunadi (2011) tax planning is a series of processes or actions carried out by taxpayers to engineer sources of income and expenses and other transactions with the aim of minimizing, deferring or eliminating tax burdens that are still within the regulatory framework. To achieve the intended purpose, employers must utilize all deductions, exceptions, exemptions, facilities and loans provided by the provisions and tax administration. If it is juxtaposed, avoidance involves mainly the commercialization and effective use of tax policies in legislation. Meanwhile, smuggling or tax evasion and the like (tax evasion) mainly occurs with disappearances or lack of reporting on tax objects which are sometimes supported by legal, accounting, and other administrative engineering. While tax aggressiveness is the act of manipulating taxable income made by companies through tax planning actions, both using methods that are classified as legal (tax avoidance) or illegal (tax evasion) (Frank et al., 2009).

Cases of tax avoidance in companies are motivated by the company's motivation to save taxes in order to avoid the tax burden that must be paid by the company. This is in accordance with the principles that are owned by the company, where the company strives to get the maximum profit by reducing the costs of the company including the cost of paying the tax burden, if necessary the company will eliminate costs to pay taxes. The act of tax aggressiveness can be an option for companies in their efforts to carry out tax avoidance. Tax aggressiveness can provide benefit margins and margin costs. The possible benefit margin is a tax saving that might be possible and have a significant impact on the company. Whereas the margin cost that might arise is the emergence of costs for the possibility of being subject to fines or tax penalties that arise when an inspection is carried out, a decline in share prices, and a loss of reputation. In this study, tax aggressiveness measures were measured using the Effective Tax Rate (ETR).

Compensation is an important component in creating an effective and conducive management. Compensation is part of management. A good compensation system can make a significant contribution to the goals to be achieved by the company, namely creating high profits. The compensation 
system can help in strengthening the organization's key values as well as facilitating the achievement of organizational goals (Sutrisno, 2016). Thomson (2002) in Kadarisman (2012) suggests that compensation is an important factor that influences how and why people work in an organization and not work with other organizations.

The policy of determining executive compensation is one way that can be done in order to encourage an increase in manager's performance. Executives have an important duty to optimize company profits for both the owner of the company and for shareholders, and in return the executive will receive compensation in accordance with the performance of the executive. The owner of the company expects the executive to continue to improve its performance to achieve maximum profit by providing the right compensation policy.

The act of tax aggressiveness can arise from various factors, one of which is compensation. Management plays an important role in choosing a strategy that is carried out by the company to increase the shareholders' wealth. This is done by improving better and more efficient performance. One way that is done by management is by efficient tax payments.

Armstrong et al. (2011) conducted a study of the relationship of compensation received by company executives, especially tax directors, to corporate tax planning. In the study, they proved that there was a strong relationship between compensation received by executives and tax planning through the Generally Accepted Accounting Principles (GAAP) Effective Tax Rate.

In addition to compensation, tax aggressiveness can also arise from various other factors. According to Francis et al. (2014) conducted a study on the representation of women as Chief
Financial Officer (CFO) in American companies registered in the ExecuComp database against acts of tax aggressiveness. From the results of these studies there was no evidence that the representation of female CFOs was different from the behavior of male colleagues in the effort of tax aggressiveness (tax avoidance). In some sectors the CFO is also responsible for data analysis.

According to the research of Palvia et al. (2014) the behavior of each gender that is between women and men is proven through decisions made by directors which tend to influence the main strategies and financial decisions that will be made. According to Arun et al. (2015) in Oyenike et al. (2016), in general, women are more careful and do not want to accept large risks so that the gender of the company's directors is considered to influence company policy and company performance. Companies that have female directors have a lower level of earnings management.

According to Francis et al. (2014) gender differences in risk-taking behavior have been extensively investigated in the psychology and economic literature, the study assesses that women generally avoid risk more than men. Women are more obedient to rules and regulations. Some arguments suggest that women do not have different preferences than their male counterparts (Atkinson et al., 2011). Institutional ownership is ownership of shares owned by the government, foreign companies, foreign investors or banks (Dewi and Jati, 2014). Because of the company's responsibility to shareholders, institutional owners have incentives to ensure that company management makes decisions that will maximize shareholder welfare. Institutional ownership based on the amount of voting rights held can force managers to focus on economic performance and avoid opportunities for 
selfish behavior. The results of the study by Khurana and Moser (2009) are the size of the concentration of institutional ownership will affect aggressive tax policy by the company.

The next factor that can influence tax avoidance activities is the size of the company. Total assets owned by the company can be used to determine the size of the company so that the greater the total assets owned by the company will also increase the amount of productivity of the company. This also has an impact on the company's profits that are increasing and affecting the level of tax payments. Rego and Wilson (2008) found in their research that the larger the company indicates that the transactions that occur are more complex. This resulted in the company taking advantage of the opportunities that exist in each of its transactions for tax avoidance efforts.

Based on this background, the research problems can be formulated as follows:

1. Does executive compensation have a significant effect on the actions of tax aggressiveness?

2. Does the representation of a female CFO have a significant effect on the actions of tax aggressiveness?

3. Does institutional ownership have a significant effect on the actions of tax aggressiveness?

4. Does the size of the company have a significant effect on the actions of tax aggressiveness?

5. Does executive compensation, representation of women's CFO, institutional ownership, and company size have a significant effect on the actions of tax aggressiveness?

\section{LITERATURE REVIEW}

\subsection{Tax Aggressiveness}

Tax aggressiveness is an act of manipulating taxable income made by the company through tax planning actions, both using methods that are classified as legal (tax avoidance) or illegal (tax evasion) (Frank et al., 2009). Balakrishnan et al. (2011) states that companies that carry out tax aggressiveness actions can be shown with lower transparency. Furthermore, Chen et al. (2010) revealed that the company is assumed to have a preference so that company management becomes more aggressive in taxation. Although tax measures taken do not violate existing regulations, but companies are increasingly taking steps to avoid taxation by utilizing the gaps of existing regulations, the action is considered increasingly aggressive. The main objective of tax aggressiveness is to make the tax burden paid lower, because the company considers the payment of income tax as a very large additional expense or transfer of wealth from the company to the government which can reduce the company's profits, therefore the company is predicted to do actions that can reduce the company's tax burden. The level of tax aggressiveness is generally influenced by the benefits and risks that will be caused. Chen et al. (2010) in his research explained that when a company decides to take action on tax aggressiveness a manager or decision maker will make a calculation of benefits and losses with his decision. Aggressive tax actions can provide marginal benefits and marginal costs.

Marginal benefits that may be obtained are:

1. The efficiency of tax benefits paid by the company to the government, so that the benefits of cash for the owners or shareholders become wider. 
2. Direct or indirect benefits for managers to obtain compensation from owners and shareholders from the actions of tax aggressiveness.

3. Benefits of opportunities for managers to display rent extraction. Rent extraction is an act of managers who do not maximize the interests of the owner, this action can be in the form of preparation of aggressive financial statements, taking company resources or assets for personal gain, or conducting transactions with special parties.

On the other hand, the marginal cost when carrying out tax aggressiveness is the possibility of obtaining sanctions or penalties from tax authorities and decreasing the company's stock price. The possibility of a decrease in stock prices is due to the assumption of shareholders that tax aggressiveness is carried out by managers for rent extraction actions that can harm shareholders (Desai and Dharmapala, 2004).

Based on the above meanings, it can be concluded that aggressive tax actions are carried out as the last attempt of a series of tax planning behaviors for the purpose of reducing tax burdens and tax savings which can later produce aggressive tax reporting. In conducting aggressive tax actions, there are several advantages and disadvantages. Chen et al. (2010) mention three advantages of tax aggressiveness actions, namely:

a. Tax savings, so that the share of cash for shareholders becomes greater.

b. Compensation for managers originating from shareholders on tax aggressiveness by the manager.

c. The opportunity for managers to do rent extraction, namely the actions of managers who do not maximize the interests of the owner. This can be in the form of the preparation of aggressive financial reports, the extraction of company resources or assets for personal gain, or conducting transactions with parties that have special relationships.

Whereas Desai and Dharmapala (2004) mention 3 losses from aggressive tax actions, namely:

a. There is a possibility that the company will be subject to penalties from tax authorities due to the discovery of frauds that may occur during the audit process

b. Damaged company reputation due to audits by tax authorities

c. The decline in the company's stock price due to the assumption of shareholders that aggressive tax actions carried out by managers are rent extraction actions that can harm shareholders. In Indonesia in the current tax laws and regulations, there is no clear definition that regulates aggressive tax planning

Government efforts to maximize revenue from the tax sector often experience obstacles. One obstacle that must be faced by the government is tax avoidance and tax evasion or various policies implemented by companies to minimize the amount of tax paid by companies, one of which is to choose the right accounting method to reduce effective tax rate (ETR). Tax avoidance is a truly legal action (Zain, 2008). Tax avoidance is in no way against the law and can even obtain tax savings by exploiting the gaps in the tax regulations. While tax evasion is an effort to minimize tax payments, but this method is done by violating tax regulations. Using effective tax rates (ETR) can be categorized as a measurement of effective planning.

Corporate tax rates (effective tax rate ( ETR) are often used as one of the references by decision makers and interested parties to make policies within the company and include the conclusions of the taxation system in the company. According to Karayan and 
Swenson (2007), one way to measure how well a company manages its tax is to look at its effective rates.

Based on the United States Government Accountability Office effective tax rate (ETR) is different from the applicable tax rate. Effective tax rates are used to measure taxes paid as a proportion of economic income, while the applicable tax rate shows the amount of tax liability relative to taxable income.

\subsection{Executive compensation}

According to Siagian (1992) in Septyani (2013), the executive is someone who occupies a certain leadership position in an organization and has the rights and authority to move other people called "subordinates" and those subordinates who bear the responsibility of carrying out various operational activities in achieving goals organization. In other words, the executive is a top-level manager of an organization, which has a large influence on the company, such as the president director, vice president director, director, executive manager including the chief commissioner and commissioner.

The policy of determining executive compensation is one way that can be done in order to encourage increased performance. Executives are responsible for optimizing the profits of the owners or shareholders, and in return the executive will receive compensation in accordance with the contract.

According to Santi and Puji (2014) in Khasanah (2015) company owners expect the executive to improve performance with appropriate compensation policies. The executive compensation package basically contains almost the same as the employee compensation package in general, which consists of basic salary components, bonuses, incentives, facilities and benefits. The difference is the existence of a type of compensation in the form of stock options (Dessler, 2007). Stock options (stock options) are rights to buy company shares at a certain price for a certain period of time, with the stock price below the market price and the price difference is a bonus (Sirait, 2007).

According to Burchman and Jones (2006) a well-designed executive compensation program can spur the growth of company performance in two ways, namely:

a. Can help companies attract people who have the right talent in certain tasks and responsibilities to drive company growth.

b. Placement of a permanent leadership position. The draft compensation plan can strengthen growth strategies through measuring performance and specific objectives that affect the growth of the company and / or business units, while reducing the turnover of management caused by poor management performance because they are not satisfied with the compensation received.

Some research on compensation is associated with agency theory. Agency theory views the relationship between the owner (principal) and company management (agent). The Principal trusts agents who provide managerial services. With this service, the agent receives compensation from the principal. Compensation is the value of services provided by company owners to management (Jensen and Meckling, 1976). Armstrong et al. (2011) conducted a study of the relationship of compensation received by company executives, especially for compensation received by tax directors to corporate tax planning. In the study, they proved the existence of a strong relationship between compensation received by the company tax director and tax planning through the Effective GAAP Tax Rate. 
Rego and Wilson (2008) also found an association between CEO and CFO compensation for company aggressive tax actions associated with company performance. Desai and Dharmapala (2004) examined how equity-based compensation incentives affect tax hedge decisions. Because equity-based incentives must align managerial interests with shareholders. Desai and Dharmapala (2004) predict that these incentives must encourage managers to reduce lease transfers and increase their tax cover. However, Desai and Dharmapala also suspect that complex tax collection transactions designed to obscure the economic substance of transactions can also obscure the company's financial statements and increase opportunities for managerial diversion. Irawan and Farahmita (2012) also found that directors' compensation had an effect on corporate tax avoidance. However, these results contradict the research conducted by Putri (2014), and Dewi and Sari (2015), the results of the second study showed that executive compensation did not affect tax avoidance.

\subsection{Female CFO representation}

Karam and Ballington (1999) in Woischnik (2012) say that the representation of women has a very important role, because it is believed to be able to provide positive change in a better policy-making process. The presence of women is a prerequisite for the realization of gender equality.

Parson and Bales (1955) in Partini (2013) reveal that women are more suitable for expressive work, while men are more suitable for instrumental work. Stoler (1982) and Boserup (1970) in Partini (2013) use the term domestic work for women and the public for men. Whereas Doringer and Piore (1971) and Stading (1978) in Partini (2013) refer to the term types of primary work for men, and secondary for women. Actually the division of labor sexually is not something that is wrong or wrong, provided that it can indicate the existence of balance (Budiman (1991) in Partini (2013)). The consequence of the division of labor is that women do not enter into the workforce, where there are differences in wages and opportunities (Carrel et al. (1995) in Partini (2013)).

Role theory pays attention to differences between sexes expressed through differences in expectations, attitudes, behaviors that have been patterned, and possible psychological characteristics. Men are considered to have higher intellect and emotions, and want meaningful work with greater expectations than women (Partini, 2013).

Men monopolize managerial jobs a lot, men are developed in such a way as to exclude women from the preparation of various programs when companies must make important decisions (Reskin and Phipps (1988) in Partini (2013)). Work is becoming increasingly bureaucratic and various kinds of personal rules that deter women are also increasingly formalized (Taylor (1977) in Partini (2013)). Heterogeneous board of directors and commissioners of the company will be able to make decisions based on evaluations of several comparable alternatives with a more homogeneous board of directors. Female directors have different work experience compared to male directors. The director of women has a better understanding of the company's market segment compared to men and this can develop quality in the company's decisionmaking process (Singh and Vinnicombe (2014) in Nathania (2014)).

Management diversity is an important thing to note regarding corporate governance in Indonesia because there is still an assumption that men are more eligible to occupy important positions in the company. Women's presence in the company is very beneficial for decision 
making. For example, women's participation in corporate boards can help avoid projects that are too risky because women are generally more risk averse than men (Byrnes et al. (1999) in Nathania (2014)) and have a high level of caution ( Kusumastuti et al. (2007) in Nathania, 2014)). Second, men and women have cognitive differences (Hambrick and Mason (1984) in Nathania 2014)), women tend to have different norms, behaviors, beliefs, and perspectives (Pelled et al. (1999) in Nathania (2014)). This cognitive pattern will allow the board to consider broader choices and solutions related to company problems (Konrad et al. (2008) in Nathania (2014)).

Gender differences in risk taking behavior have been extensively explored in the fields of literature and literary economics. Existing studies show that women are generally more risk-averse than men (Francis et al., 2014).

Whereas Aspray and Cohoon (2009) in Arini et al. (2010) state that there is a relationship between gender roles and risk-taking behavior, namely feminine gender roles are more likely to produce higher risk-taking behavior.It is this gender role that influences people's views on the nature and behavior that should be displayed by certain sexes. Though it is uncertain that generalizations can be made to all people who have the same sex because everyone also has individual uniqueness (Hyde (2007) in Arini et al. (2010)). Although it can facilitate social categorization, there are also negative impacts of gender roles, namely attributive errors of aggressiveness and achievement. Men are seen as having a high level of aggressiveness when in fact not all men are like that. Women are always considered to have no desire for achievement, therefore there is a double standard for women, namely women must work extra hard to get success and gain recognition from the community (Hyde (2007) in Arini et al., (2010)).

Research conducted by Vermeir and Kenhove (2008) shows that women tend to be more ethical in making judgments and behavior than men. While Barber and Odean (2000) state that women tend to avoid risks compared to men.It can be said that gender differences from top management companies will influence decision making and direction of company policy. Associated with earnings management, gender differences from top management companies certainly can be assumed to have implications for earnings management practices and financial reporting quality. Peni and Vahaama (2010) state that the existence of one of the CEOs of women or a female CFO will reduce the level of earnings management. Whereas Baruan et al. (2010) in Francis et al. (2014) state that female CFOs have an influence on earnings management.

Meanwhile, Francis et al. (2014) do not determine that the representation of female samples as CFOs is different from the behavior of male colleagues in an effort to aggressively tax (tax avoidance). In other words, the representation of women as CFO does not significantly influence the actions of tax aggressiveness.

\subsection{Institutional Ownership}

Jensen and Meckling (1976) state that institutional ownership has a very important role in minimizing agency conflicts that occur between managers and shareholders. The existence of institutional investors is considered capable of being an effective monitoring mechanism in every decision taken by the manager. This is because institutional investors are involved in strategic retrieval so it is not easy to believe in the act of profit manipulation.

Institutions can be foundations, banks, insurance companies, investment 
companies, pension funds, companies in the form of companies (PT), and other institutions. The existence of institutional ownership in a company will encourage an increase in more optimal supervision of management performance. Supervision carried out by institutional investors is very dependent on the amount of investment made. Institutions that control shares are larger than other shareholders can supervise the management policies that are also greater so that management will avoid behavior that is detrimental to shareholders. The greater institutional ownership, the stronger control is exercised.

In Annisa and Lulus's (2012) study states that institutional owners play an important role in monitoring, disciplining and influencing managers. They argue that institutional owners should be based on the size and voting rights they have, which can force managers to focus on economic performance and avoid opportunities for selfish behavior.

The existence of corporate responsibility to the owner, the institutional owner has an incentive to ensure that management makes decisions that will maximize the welfare of shareholders. The existence of institutional investors also indicates pressure from investors to company management to carry out tax avoidance policies in order to obtain maximum profits for institutional investors (Dewi and Jati, 2014).

According to Fadhilah (2014) the size of the concentration of institutional ownership will affect aggressive tax policies, but the greater the institutional ownership will further reduce aggressive tax policy actions.

Research from Pranata et al. (2013) stated that the size of the concentration of institutional ownership would affect the aggressive tax policy by the company. Khurana and Moser (2009) also stated that the greater concentration of short-term shareholder institutions would increase aggressive tax policies, but the greater the concentration of ownership of long-term shareholder institutions would further reduce aggressive tax policy actions. Tax aggressiveness leads to tax savings that cause potential companies to be subject to sanctions by the IRS (Internal Revenue Service) related to implementation costs and agency costs. (Chen et al. (2008) in Annisa and Lulus (2012)). Companies with greater institutional ownership are more likely to issue, predict and predict something more specific, accurate, and optimistic (Khurana and Moser, 2009).

The greater the institutional ownership, the greater the supervision carried out by external parties. The company's management will carry out policies to optimize the value of the company so that the company's performance will increase. External shareholders have incentives to monitor and influence management fairly to protect their investment in the company. External shareholders reduce manager's opportunistic behavior, resulting in a low direct agency conflict between management and shareholders (Wahidahwati, 2002).

\subsection{Company Size}

The size of the company is basically grouping into several groups, including large companies, medium-sized companies and small companies. Company scale is a measure used to reflect the size of the company based on the company's total assets.

According to Kieso (2014) the notion of assets is:"As a result of this event, it will be expected to flow to the entity."

The statement above explains that assets are resources that are controlled by a company as a result of a past event and are expected to get future economic benefits for the company. 
According to Bestivano (2013) company size can be measured using the total assets, income or capital of the company. One benchmark that shows the size of the company is the size of the assets of the company. Companies that have a large total assets show that the company has reached maturity, where at this stage the company's cash flow has been positive and is considered to have good prospects in a relatively stable period and more able to generate profits than companies with small total assets.

\subsection{Hypothesis}

2.6.1 Effects of Executive Compensation on Actions of Tax Aggressiveness

Compensation is an important component in creating an effective and conducive management. Compensation is part of management. A good Compensation System can contribute significantly to business success. The compensation system helps in strengthening the organization's key values and facilitates the achievement of organizational goals (Sutrisno, 2016).

Thomson (2002) in Kadarisman (2012) suggests that compensation is an important factor that influences how and why people work in an organization and not other organizations. The policy of determining executive compensation is one way that can be done in order to encourage increased performance.

Rego and Wilson (2008) also found a relationship between $\mathrm{CEO}$ and $\mathrm{CFO}$ compensation for corporate tax aggressiveness associated with company performance. Then, Irawan and Farahmita (2012) also found that directors' compensation had an effect on corporate tax avoidance. Therefore, the hypothesis in this study is formulated as follows:

Ha1: Executive compensation has a significant influence on the act of tax aggressiveness.

\subsubsection{Effect of Women's CFO Representation on Tax Aggression Actions \\ CFO is a position in a company that} has the primary responsibility for managing the company's financial risk. In some sectors the $\mathrm{CFO}$ is also responsible for analyzing the data. In corporate financial reporting the $\mathrm{CEO}$ and $\mathrm{CFO}$ are the parties involved who directly sign the financial statements and are responsible for the information presented.

According to Aspray and Cohoon (2007) in Arini et al. (2010) state that there is a relationship between gender roles and risk-taking behavior, namely feminine gender roles are more likely to produce higher risk-taking behavior. Therefore, the hypothesis in this study is formulated as follows:

Ha2: Representation of CFO for Women has a significant influence on the actions of tax aggressiveness.

\subsubsection{Effect of Institutional Ownership on Measures of Tax Aggressiveness}

The existence of institutional investors is considered capable of being an effective monitoring mechanism in every decision taken by the manager. This is because institutional investors are involved in strategic retrieval so it is not easy to believe in the act of profit manipulation. The size of the concentration of institutional ownership will affect the policy of tax aggressiveness by the company.

In the research of Shleifer and Vishney (1986) in Annisa and Lulus (2012) states that institutional owners play an important role in monitoring, disciplining, and influencing management. Therefore the hypothesis is formulated as follows:

Ha3: Institutional ownership has a significant influence on the act of tax aggressiveness. 


\subsubsection{Effect of Company Size on Tax Aggressiveness Measures}

The size of the company is the scale that determines the size of the company that can be seen from equity, company value, number of employees and total asset value which is a context variable that measures the demands of service or product of the organization. Based on the research conducted by Swingly and Sukartha (2015) there is an influence between the size of the company and tax avoidance by the company. So based on the description above, the following hypotheses can be formulated:

Ha4: Company size has a significant influence on tax aggressiveness.

\section{RESEARCH METHOD}

\subsection{Population and sample}

The data used in this study uses secondary data, namely in the form of financial statements from manufacturing companies that listed on the Indonesia Stock Exchange in 2014-2016 with a population of 149 companies

The criteria set by the author to take samples are as follows:

1. Manufacturing companies consistently listed on the Indonesia Stock Exchange (IDX) during 20142016.

2. Manufacturing companies that publish annual reports and financial statements in full from 2014-2016.

3. Manufacturing companies that use the rupiah as a currency in their financial statements.

4. Manufacturing companies that have not suffered losses during the period 2014-2016.

5. Manufacturing companies that have complete data related to the variables used in this study during the period 2014-2016

obtained a sample of 47 companies with an observation period of 3 years to obtain a sample of 141 .

\subsection{Data Analysis Techniques}

The author tabulates the data by using Microsoft Excel to input and calculate the independent variables and dependent variables. After the data tabulation was done, the authors conducted descriptive statistical analysis, testing classical assumptions in the regression model and testing hypotheses using IBM SPSS Statistics 23.

\subsection{Operational Definitions of Variables}

3.3.1 Independent variable

a. Executive compensation

Compensation is an important component in the creation of an effective and conducive management. Compensation is part of management. A good compensation system can contribute significantly to business success. The compensation system helps in strengthening the organization's key values and facilitates the achievement of organizational goals (Sutrisno, 2016). Compensation is a determinant of company policy decisions. In this study using a proxy carried out by Armstrong et al. (2011), which only tests the level of compensation given to the executive board. This study uses a proxy of natural logarithms from the total value of compensation received by directors and commissioners for one year (Putri, 2014). Executive board compensation data is contained in the disclosure of Notes to the Company's Financial Statements.

b. Female CFO representation In this study the level of representation of women was measured by the representation of women as CFOs in the board of directors of a company. The CFO is responsible for managing the company's financial risk. The $\mathrm{CFO}$ is also responsible for financial 
planning and recording, as well as financial reporting for higher management.In some sectors the CFO is also responsible for data analysis. This variable is proxied by a dummy variable, if the company has a female $\mathrm{CFO}$ rated 1 (one) and if it does not have a $\mathrm{CFO}$, women are given a value of 0 (zero) (Francis et al., 2014).

\section{c. Institutional Ownership}

According to Ujiyantho and Pramuka (2007) institutional ownership is the proportion of share ownership by institutions such as NGOs, private companies, securities companies, pension funds, insurance companies, banks, and investment companies. Institutional ownership has an important role in monitoring, disciplining and influencing managers. They argue that institutional owners should be based on the size and voting rights they have, which can force managers to focus on economic performance and avoid opportunities for selfish behavior. Institutional ownership is measured by the number of institutional shares divided by the total outstanding shares.

\section{d. Company Size}

According to Bestivano (2013: 6) company size can be measured using the total assets, income or capital of the company. One benchmark that shows the size of the company is the size of the assets of the company. Companies that have large total assets show that the company has reached the maturity stage, where at this stage the company's cash flow is positive and is considered to have good prospects in a relatively stable period and more able to generate profits compared to companies with small total assets. Companies that have a large total assets show that the company has reached maturity, where at this stage the company's cash flow has been positive and is considered to have good prospects in a relatively stable period and more able to generate profits than companies with small total assets. Measurements can be made using the natural logarithmic formula of total assets.

\subsubsection{Dependent Variable}

The dependent variable in this study is the act of tax aggressiveness. In this study, tax aggressiveness measures were measured using the Effective Tax Rate (ETR) in measuring the level of tax aggressiveness. Effective Tax Rate (ETR) is used as a measurement because it is considered to reflect a fixed difference between book profit calculation and fiscal profit (Frank et al, 2009). Effective Tax Rate (ETR) is calculated by dividing the total corporate tax expense by profit before income tax.

$$
\mathrm{ETR}=\frac{\text { total tax expense }}{\text { pretax income }}
$$

The difference in ETR with the applicable tax rate can be seen as a form of tax avoidance but can also be seen as a form of tax planning carried out by the entity. If the ETR value is higher than the applicable tax rate, it can be said that there is no tax aggression and vice versa if the ETR value is lower than the applicable tax rate, it can be said that there is tax aggressiveness. According to Lestari et al. (2015) company effective tax rate (ETR) is often used as one of the references by decision makers and interested parties to make policies within the company and include tax system conclusions on the company. According to Karayan and Swenson (2007), one way to measure how well a company manages its tax is to look at its effective tax rate. The effectiveness of the company's efforts to minimize its tax burden is seen through the company's 
effective tax rate (ETR). Basically, effective tax rate (ETR) is a comparison between tax obligations resulting from taxable income based on tax regulations, to the accounting lab based on accounting standards.

\subsection{Data Analysis Techniques}

The author tabulates the data by using Microsoft Excel to input and calculate the independent variables and dependent variables. After the data tabulation was done, the authors conducted descriptive statistical analysis, testing classical assumptions in the regression model and testing hypotheses using IBM SPSS Statistics 23.

\section{RESULTS AND DISCUSSION}

\subsection{Results}

The results of multiple linear regression testing can be seen in table 4.1.

\section{Tabel 1}

Test Results for Multiple Linear Regression Coefficients $^{a}$

\begin{tabular}{|c|c|c|c|c|}
\hline \multirow{2}{*}{\multicolumn{2}{|c|}{ Model }} & \multicolumn{2}{|c|}{ Unstandardized Coefficients } & \multirow{2}{*}{$\begin{array}{c}\begin{array}{c}\text { Standardized } \\
\text { Coefficients }\end{array} \\
\text { Beta }\end{array}$} \\
\hline & & $\mathrm{B}$ & Std. Error & \\
\hline \multirow[t]{5}{*}{1} & (Constant) &, 365 &, 063 & \\
\hline & KOMP &,- 013 & ,006 &,- 474 \\
\hline & $\mathrm{CFO}$ & ,017, & ,010 & ,164 \\
\hline & $\begin{array}{l}\text { KEPEMILIKAN } \\
\text { INSTITUSIONAL }\end{array}$ & ,001 & 016 & ,003 \\
\hline & SIZE & 007 & 005 & ,302 \\
\hline
\end{tabular}

a. Dependent Variable: ETR

Source: Data Processing Results with SPSS 23 (2017)

From table 1, the regression equation can be made as follows:

$$
\begin{aligned}
& \mathrm{ETR}=0.365-0.013 \mathrm{KOMP}+ \\
& 0.017 \mathrm{CFO}+0.001 \mathrm{KEPINS}+ \\
& 0.007 \mathrm{SIZE}+\varepsilon
\end{aligned}
$$

Information:

ETR $=$ Effective Tax Rate

KOMP = Executive Compensation

$\mathrm{CFO}=$ Female $\mathrm{CFO}$ Representation

KEPINS = Institutional Ownership

SIZE $=$ Company Size

The regression equation above shows a constant value of 0.365 . This means that if the executive compensation variable, female CFO representation, institutional ownership and company size are considered constant or worth 0 (zero), the Effective Tax Rate (ETR) will increase by 0.365 units or it can be said that tax aggressiveness will decrease by 0.365 units.

Regression coefficient value on executive compensation variable is 0,013 , this means that if the executive compensation variable increases by 1 (one) unit then the ETR variable will decrease by $-0,013$ units assuming other variables are considered constant. The regression coefficient on the variable female CFO representation is 0.017 , this means that if the variable representation of female CFO increases by 1 (one) unit then the ETR variable will increase by 0.017 units, assuming other variables are considered constant. 
Regression coefficient values on institutional ownership variables are 0.001 , this means that if institutional ownership variables increase by 1 (one) unit, the ETR variable will increase by 0.001 units, assuming other variables are considered constant.

The regression coefficient on the variable size of the company is 0.007 , this means that if the variable size of the company increases by 1 (one) unit then the ETR variable will increase by 0.007 units, assuming other variables are considered constant.

\subsubsection{Determination Coefficient Test}

The coefficient of determination in this study is based on the value of Adjusted R Square. The test results of the coefficient of determination can be seen in Table 4.2.

Table 2

Determination Coefficient Test Results

Summaryb model

\begin{tabular}{|l|r|r|r|c|}
\hline Model & \multicolumn{1}{|c|}{$\mathrm{R}$} & \multicolumn{1}{c|}{ R Square } & Adjusted R Square & $\begin{array}{c}\text { Std. Error of the } \\
\text { Estimate }\end{array}$ \\
\hline 1 &, $287^{\mathrm{a}}$ &, 082 &, 049 &, 03890601 \\
\hline
\end{tabular}

a. Predictors: (Constant), SIZE, KEPEMILIKAN INSTITUSIONAL, CFO, KOMP

b. Dependent Variable: ETR

Source: Data Processing Results with SPSS 23 (2017)

Based on the table above it is known that the Adjusted $\mathrm{R}$ Square value is 0.049. This means that the independent variables used in this study, namely executive compensation, female CFO representation, institutional ownership, and company size can explain the dependent variable of $4.9 \%$ while the remainder is $95.1 \%(100 \%-4,9 \%)$ are explained by other variables not examined in this study.

\subsubsection{Uji-t}

Tabel 3

Hasil Uji-t

\begin{tabular}{|c|c|c|c|c|c|c|}
\hline \multirow{2}{*}{\multicolumn{2}{|c|}{ Model }} & \multicolumn{2}{|c|}{$\begin{array}{c}\text { Unstandardized } \\
\text { Coefficients }\end{array}$} & \multirow{2}{*}{$\begin{array}{c}\begin{array}{c}\text { Standardized } \\
\text { Coefficients }\end{array} \\
\text { Beta } \\
\end{array}$} & \multirow[b]{2}{*}{$\mathrm{T}$} & \multirow[b]{2}{*}{ Sig. } \\
\hline & & B & $\begin{array}{l}\text { Std. } \\
\text { Error }\end{array}$ & & & \\
\hline \multirow[t]{5}{*}{1} & (Constant) & ,365 & ,063 & & 5,782 & ,000 \\
\hline & KOMP &,- 013 & ,006 &,- 474 & $-2,246$ & ,027 \\
\hline & $\mathrm{CFO}$ & , 017 & ,010 & , 164 & 1,751 & ,083 \\
\hline & $\begin{array}{l}\text { KEPEMILIKAN } \\
\text { INSTITUSIONAL }\end{array}$ & ,001 & 016, & 003, & ,033 & 974 \\
\hline & SIZE &, 007 & ,005 & ,302 & 1,426 & ,157 \\
\hline
\end{tabular}

a. Dependent Variable: ETR

Source: Results of Data Processing with SPSS 23 


\subsubsection{Test $\mathrm{F}$ Statistics}

To find out whether executive compensation, representation of women's CFO, institutional ownership and size of the company have an effect on simultaneously on tax aggressiveness, the $\mathrm{F}$ test is carried out. The $\mathrm{F}$ test results can be seen in Table 4.4.

Tabel 4.4

F Test Results ANOVA ${ }^{a}$

\begin{tabular}{|c|c|c|c|c|c|c|}
\hline \multirow{2}{*}{\multicolumn{2}{|c|}{ Model }} & \multicolumn{2}{|c|}{$\begin{array}{l}\text { Unstandardized } \\
\text { Coefficients }\end{array}$} & \multirow{2}{*}{\begin{tabular}{|c|}
$\begin{array}{c}\text { Standardize } \\
\mathrm{d} \\
\text { Coefficients }\end{array}$ \\
Beta \\
\end{tabular}} & \multirow[b]{2}{*}{$\mathrm{T}$} & \multirow[b]{2}{*}{ Sig. } \\
\hline & & $\mathrm{B}$ & Std. Error & & & \\
\hline & (Constant) &, 365 & ,063 & & 5,782 &, 000 \\
\hline & KOMP &,- 013 & ,006 &,- 474 & $-2,246$ & ,027 \\
\hline & $\mathrm{CFO}$ & 017 & ,010 & , 164 & 1,751 & ,083 \\
\hline & $\begin{array}{l}\text { KEPEMILIKAN } \\
\text { INSTITUSIONAL }\end{array}$ & 001, & ,016 & ,003 & ,033 & ,974 \\
\hline & SIZE & 007 & ,005 & 302 & 1,426 & ,157 \\
\hline
\end{tabular}

a. Dependent Variable: ETR

b. Predictors: (Constant), SIZE, KEPEMILIKAN INSTITUSIONAL, CFO, KOMP

Source: Data Processing Results with SPSS 23 (2017)

\subsection{Discussion}

\subsubsection{Effects of Executive} Compensation on Tax Aggressiveness Measures

Based on the results of the test, it was found that the significance value of the executive compensation variable was $0.027<0.05$ so that it could be concluded that executive compensation had a significant effect on tax aggressiveness or Ha1 was accepted. The regression coefficient value of the executive compensation variable of 0.013 shows that the effect of executive compensation has a negative direction on ETR, so it can be concluded that the greater the amount of executive compensation, the lower the ETR value or the higher level of tax aggressiveness.

This study supports the results of research conducted by Desai and Dharmapala (2004), Rego and Wilson (2008), and Armstrong et al. (2011) who found that executive compensation proxied by natural logarithms from the total compensation received by the executive for one year affected tax aggressiveness. This indicates that compensation is one of the things that motivates corporate executives to take action on tax aggressiveness. The higher it is compensation then ETR decreases so that it indicates the existence of tax aggressiveness by the company. So that executive compensation that is right for executives is considered to be an effective way to achieve corporate tax efficiency efforts.

4.2.2 Effect of Women's CFO Representation on Tax Aggression Actions

Based on the $t$ test, it was found that the significance value of the variable female CFO representation was 0.083 > 0.05 so that it could be concluded that the representation of the female CFO had no significant effect on tax aggressiveness so $\mathrm{Ha} 2$ was rejected. These results support the results of the study of Francis et al. (2014). The 
limitations of the number of samples and years for the representation of female CFOs compared to the number of male CFOs in manufacturing companies in Indonesia for the 2014-2016 period were thought to be differences in results with previous studies. Another possibility, if previously the dependent variable tested was earnings management, this time the researcher tested the tax aggressiveness that had previously been done for American companies listed in the ExecuComp database (Francis et al. 2014). Country differences and the number of samples also found mutually supportive results, that between female CFO representation and tax aggressiveness had no effect. This is due to the low opportunities women have and the assumption that women do not have the desire and ability to achieve, therefore women who get high positions will strive to achieve double standards, namely by gaining success and gaining recognition from the community. So that gender differences do not affect decision making, policy direction, consideration and risk.

\subsubsection{Effect of Institutional Ownership on Acts of Aggressiveness Tax}

Based on the results of the test, it was found that the significance value of institutional ownership variables was 0.974> 0.05 so that it could be concluded that institutional ownership variables did not significantly influence the aggressiveness of the tax so that $\mathrm{Ha} 3$ was rejected. These results support the research conducted by Annisa and Tulus (2012) where institutional ownership does not affect tax avoidance. This shows that institutional shareholders are not focused on the role of monitoring, disciplining and influencing management. This should force management to avoid selfish behavior, but institutional owners also have incentives to ensure that management makes decisions that can maximize the welfare of institutional shareholders.

\subsubsection{The Effect of Company Size on Tax Aggressiveness}

Based on the results of the test, it was found that the variable significance value of firm size was $0.157>0.05$ so it can be concluded that the variable size of the company did not significantly influence the aggressiveness of the tax so $\mathrm{Ha} 4$ was rejected.

The results of the study support the research conducted by Rusydi (2014). These results indicate that the size of the company does not affect the tax aggressiveness action, which means that the company's behavior to conduct tax aggressiveness is not influenced by the size of the company. The idea that tax is a burden, is currently still the main focus of the company so that tax aggressiveness becomes a strategy for all companies.

\section{CONCLUSION}

Based on the research that has been done, the conclusions that can be given are as follows:

1. Variable executive compensation has a significant positive effect on tax aggressiveness. This indicates that compensation is one of the things that motivates corporate executives to take action on tax aggressiveness. The higher the compensation, the ETR goes down so it indicates the higher the level of tax aggressiveness carried out by the company. So that executive compensation that is right for executives is considered to be an effective way to achieve corporate tax efficiency efforts.

2. Variable representation of female CFO does not have a significant effect on tax aggressiveness. This is due to the low opportunities women have and the assumption that women do not have the desire and ability to achieve, therefore women who get high positions will strive to achieve 
double standards, namely by gaining success and gaining recognition from the community. So that it can be concluded that gender differences do not affect decision making, policy direction, consideration and risk, related to tax planning strategies.

3. Variable institutional ownership does not have a significant effect on tax aggressiveness. This indicates that the shareholders Institutions are less focused on the role of monitoring, disciplining and influencing management.

4. Variable size of the company does not have a significant influence on tax aggressiveness. These results indicate that the size of the company does not affect the tax aggressiveness, which

\section{REFERENCES}

Annisa, A. N., \& Lulus, K. (2012). Pengaruh Corporate Governance terhadap Tax Avoidance. Universitas Sebelas Maret.

Arikunto, S. (2013). Manajemen Penelitian. Jakarta: Bhineka Cipta.

Arini, R., Mangundjaja, W., \& TB, G. H. (2010). Hubungan Peran Gender dan Tingkah Laku Pengambilan Resiko Pada Wirausaha Perempuan dengan Usaha Kecil. Jurnal ISSN, 1 .

Ariyanti, F. (2006). Membongkar Strategi Penghindaran Pajak Google di Dunia. https://www.liputan6.com/amp/262 6083/membongkarstrategipenghindaran-pajak-googledi-dunia. Diakses tanggal 22 September 2017

Armstrong, S. C., Jennifer, B. L., \& David F, L. (2011). The Incentives for Tax Planning. SSRN Working Paper Series. means that the company's behavior to carry out tax aggressiveness is not influenced by the size of the company. The idea that taxes are a burden, is currently still the main focus of entrepreneurs so that tax aggressiveness becomes a strategy for all companies regardless of the size of the company.

5. Variables of executive compensation, representation of female $\mathrm{CFO}$, institutional ownership and company size have a significant influence on tax aggressiveness. This indicates that the independent variables together have a simultaneous influence on the dependent variable.

Atkinson, R., Atkinson, R., \& Hilgrad, E. (2011). Pengantar Psikologi (Vol. 1). Jakarta: Erlangga.

Balakrishnan, K., Blouin, J., \& Guay, W. (2011). Does Tax

Aggressiveness Reduce Financial Reporting Transparency? Working Paper of Pennsylvania.

Barber, M. Brad \& Odean.T (2000). Trading is Hazardous to Your Wealth: The Common Stock Investment Performance of Individual Investors. Journal of Finance 55(2): 773-806.

Bestivano, W. (2013). Pengaruh Ukuran Perusahaan, Umur Perusahaan, Profitabilitas dan Financial Leverage terhadap Perataan Laba pada Perusahaan yang Terdaftar di BEI. Jurnal Universitas Negeri Padang.

Burchman, S., \& Jones, B. (2006). Executive Compensation as a Support for a Growth Strategy. World of Work Journal . 
Brigham, F. E., Gapenski, C. L., \& Ehrhardt, C. M. (1999). Financial Management: Theory and Practice. Dryden Press.

Chen, S., Chen, X., \& Shelvin, T. (2010). Are Family Firms More Tax Aggresive than Non-Family Firms? Journal of Financial Economics.

Cooper, D. R., \& Pamela, S. (2003). Business Research Methods (8 ed.). New York: McGraw-Hill/Irwin.

Copeland, T., \& Weston, J. F. (1992). Managerial Finance (9 ed.). Orlando Florida: The Dryden Press.

Desai, M., \& Dharmapala, D. (2004). Corporate Tax Avoidance and High Powered Incentive. Economics Working Paper.

Dessler, G. (2007). Manajemen Sumber Daya Manusia. Jakarta: Indeks.

Dewi, G. P., \& Sari, M. R. (2015). Pengaruh Insentif Eksekutif, Corporate Risk dan Corporate Governance Pada Tax Avoidance. Jurnal Akuntansi Universitas Udayana.

Dewi, N., \& Jati, I. (2014). Pengaruh Karakter Eksekutif, Karakteristik Perusahaan, dan Dimensi Tata Kelola Perusahaan yang Baik pada Tax Avoidance di Bursa Efek Indonesia. E-Jurnal Akuntansi Universitas Udayana.

Dyreng, S., Hanlon, M., \& Maydew, E. (2010). The Effects of Executives on Corporate Tax Avoidance. The Accounting Review, 85(4).

Eisenhardt, K. (1989.). Agency Teory : An Assessment and Review. Academy of Management Review, 14, 41-53.

Fadhilah, R. (2014). Pengaruh Good Corporate Governance Terhadap Tax Avoidance. E-journal Universitas Negeri Padang.

Fakih, M. (2016). Analisis Gender dan Transformasi Sosial. Yogyakarta: Insist Press dan Pustaka Belajar.
Francis, B., Hasan, I., Wu, Q., \& Yan, M. (2014). Are Female CFOs Less Tax Aggresive? Evidence from Tax Aggresiveness. Bank of Finland Research, 16.

Frank, Margaret, M., Lynch, L., \& Rego, O. S. (2009). Tax Reporting Aggressiveness and Its Relation to Aggressive Financial Reporting. The Accounting Review of American Accounting Association.

Ghozali, I. (2013). Aplikasi Analisis Multivariate dengan Program IBM SPSS 21 Upgrade PLS Regresi. Semarang: Badan Penerbit Universitas Diponogoro.

Ghozali, I. (2016). Aplikasi Analisis Multivariate dengan Program IBM SPSS 23. Badan Penerbit Universitas Diponogoro.

Gunadi. (2011). Akuntansi Perpajakan (Edisi Revisi ed.). Jakarta: Grasindo.

Hakim, K. (2011). Pengaruh Kompensasi dan Motivasi Terhadap Produktivitas Kerja Pegawai. Jurnal Manajemen dan Bisnis, 11(2).

Hartono, J. (2013). Teori Portofolio dan Analisis Investasi. (8, Ed.) Yogyakarta: BPFE.

Ika, A. Komisi Eropa Selidiki Kasus Penghindaran Pajak oleh IKEA. ekonomi.kompas.com/read/2016/02 /16/101041226/Komisi.Eropa.Selid iki.

Kasus.Penghindaran.Pajak.oleh.IK EA. Diakses tanggal 22 September

Irawan, H., \& Farahmita, A. (2012). Pengaruh Kompensasi Manajemen dan Corporate Governance terhadap Manajemen Pajak Perusahaan. Jurnal Universitas Indonesia.

Jensen, M., \& Meckling, W. (1976). Theory of The Firm: Managerial Behavior, Agency Costs and Owership Structure. Journal of Financial Economics, 3(4). 
Jensen, M. C., \& Smith, C. W. (1984). Stockholder, Manager, and Creditor Interests: Applications of Agency Theory. Homeword: Richard Irwin.

Kadarisman, M. (2012). Manajemen Kompensasi. Jakarta:Raja grafindo.

Karayan, J. E., Swenson, C. W. (2007). Stategic Business Tax Planning. 2nd edition. New Jersey: John Wiley \& Sons Inc.

Kartikarini, N., \& Mutmainah, S. (2013). Analisis Pengaruh Diversitas Gender terhadap Voluntary Corporate Governance Disclosure dalam Laporan Tahunan Perusahaan. E-Jurnal UNDIP, 2(1).

Khasanah, I. (2015). Pengaruh Kompensasi Manajemen Eksekutif Terhadap Kinerja Keuangan Perusahaan (Pada 50 Perusahaan Best of The Best Versi Majalah Forbes Indonesia tahun 2013). Jurnal Akuntansi Fakultas Ekonomi Universitas Negeri Surabaya.

Khurana, I., \& Moser, W. (2009).

Institusional Ownership and Tax Aggressiveness.

Kieso, D. E., Weygandt, J., \& Warfield, T. (2014). Intermediate Accounting (IFRS ed.). United States of America: John Wiley \& Sons Inc.

Nalikka, A. (2009). Impact of Gender Diversity on Voluntary Disclosure in Annual Report. Accounting and Tax Journal.

Nathania, A. (2014). Pengaruh Komposisi Dewan Perusahaan Terhadap Profitabilitas Perusahaan. Finesta, 2(1).

Nitisemito, A. (2010). Manajemen Personalia. Jakarta: Ghalia Indonesia.

Noviyanto. (2011). Sistem Informasi Sumber Daya Manusia. Working Paper Universitas Gunadarma.

Oyenike, O., Olayinka, E., \& Francis, E. (2016). Female Directors and Tax Aggressiveness of Listed Bank in
Nigeria. $3 r d$ International Conference on African Development Issues, 293-299.

Palvia, Vahamaa, E., \& Vahamaa, S. (2014). Are Female CEOs and Chairwomen more Conservative and Risk Averse? Evidence from the Banking Industry during the Financial Crisis. Journal of Business Ethics, 131, 577-594.

Partini. (2013). Bias Gender dalam Birokrasi (2 ed.). Yogyakarta: Tiara Wacana.

Peni, E., \& Vahamaa, S. (2010). Female Executives and Earnings Management. Journal of Managerial Finance, 36(7).

Pranata, F. M., Puspa, D. D., \& Herawati. (2013). Pengaruh Karakteristik Eksekutif dan Corporate Governance Terhadap Tax Avoidance. Jurnal Akuntansi Universitas Dian Nuswantoro.

Putri, F. N. (2014). Pengaruh Karakteristik Kepemilikan dan Kompenssasi Eksekutif terhadap Tax Aggressive (Studi Empiris Pada Perusahaan Manufaktur yang Terdaftar di BEI). Jurnal Fakultas Ekonomi Universitas Negeri Padang.

Rego, S. O., \& Wilson, R. (2008). Executive Compensation, Tax Reporting Aggressiveness, and Future Firm Performance. Working Paper of University Iowa.

Republik Indonesia. Undang-Undang No 28 Tahun 2007 Tentang Tata Cara dan Ketentuan Umum Perpajakan.

Resmi, S. (2014). Perpajakan : Teori dan Kasus. Jakarta: Salemba Empat.

Rori , H. (2013). Analisis Penerapan Tax Planning atas Pajak Penghasilan Badan. 1(3), 410-418.

Rusydi, M. K., \& Martani, D. (2014). Pengaruh Struktur Kepemilikan Terhadap Aggresive Tax 
Avoidance . SNA 17 Mataram, Lombok Universitas Mataram.

Septyani, I. (2013). Peranan Eksekutif dalam Mengarahkan Perusahaan Melalui Persaingan dalam Perencanaan Jangka Panjang. Jurnal Universitas Gunadarma.

Sirait, J. (2007). Memahami Aspekaspek Pengelola Sumber Daya Manusia dalam Organisasi. Jakarta : Grasindo.

Sugiyono. (2013). Statistik Untuk Penelitian. Bandung: Alfabeta.

Suryowati, E. (2016). Terkuak, Modus Penghindaran Pajak Perusahaan Jasa Kesehatan Asal Singapura.ekonomi.kompas.com/re $\mathrm{ad} / 2016 / 04 / 06 / 203829$

826/Terkuak.Modus.PenghindaranP ajak.Perusahaan.Jasa.Kesehatan.As al. Singapura. Diakses tanggal 22 September

Sutrisno, E. (2016). Manajemen Sumber Daya Manusia. Jakarta: Predana Mediia Group.

Swingly, C., \& Sukartha, I. (2015). Pengaruh Karakter Eksekutif, Komite Audit, Ukuran Perusahaan,
Leverage dan Sales Growth Pada Tax Avoidance. EJurnal Akuntansi Universitas Udayana 10.1, 47-62.

Ujiyantho, M. A., \& Pramuka, B. A. (2007). Mekanisme Corporate Governance, Manajemen Laba dan Kinerja Keuangan. SNA $X$ Semarang.

Vermeir, I., \& Kenhove, P. V. (2008). Gender Difference in Double Standards. Journal of Business Ethics.

Wahidahwati. (2002). Kepemilikan Manajerial dan Agency Conflicts: Analisis Persamaan Simultan Non Linier dari Kepemilikan Manajerial, Penerimaan Risiko (Risk Taking), Kebijakan Utang dan Kebijakan Dividen. Simposium Nasional Akuntansi, 5, 601-625.

Waluyo. (2014). Perpajakan Indonesia. Jakarta: Salemba Empat.

Wibowo. (2016). Manajemen Kinerja (5 ed.). Jakarta: Rajagrafindo.

Woischnik, J. (2012). Perempuan, Partai Politik, dan Parlemen. Jakarta: Gading Inti Prima. 